\title{
CORPORATE GOVERNANCE ATTRIBUTES AND LISTED SMES' DEBT MATURITY
}

\author{
Anahí BRIOZZO \\ Universidad Nacional del Sur, Argentina \\ Clara CARDONE-RIPORTELLA \\ Universidad Pablo de Olavide, Spain \\ Myriam GARCÍA-OLALLA \\ Universidad de Cantabria, Spain
}

\begin{abstract}
Purpose: This article develops a cross-country analysis of the similarities and differences in the debt maturity structure of listed SMEs from the point of view of CG attributes in two different economic environments: an OECD (Spain) country and a non-OECD (Argentina) country.
\end{abstract}

Design/methodology/approach: Using data from listed SMEs in the Argentinian SME segment (pooled data from 2012 to 2015) and listed SMEs in the Spanish Mercado Alternativo Bursátil for growing firms (MAB_GE 2014), bivariate and multivariate analyses are performed.

Findings: Spanish firms with a higher ownership concentration and a large controlling shareholder have higher short-term liabilities (STL) ratios. Participation of women on the board has a negative relation with the STL ratio only for Spain. The participation of corporations in ownership and a Big4 auditor have a negative relation with the STL ratio for both countries.

Practical implications: These results will help SME managers understand the effects of the application of good governance policies. The study also gives regulators a guideline to develop standards to assist in efficient borrowing in terms of seeking funding in alternative capital markets. 
Originality/value: First, the results provide evidence about the financial impact on the STL ratio of CG attributes in listed SME. Second, as far as the authors know, this is the first article to analyse the CG attributes of listed SMEs in an OECD country and a non-OECD country. Third, the paper presents CG data derived from an ad hoc basis elaborated from different websites and databases.

Keywords: corporate governance, SMEs, financial management, OECD country and non-OECD country

Article Classification: Research paper

\section{INTRODUCTION}

A growing body of research has begun to analyse the impact of applying corporate governance (CG) recommendations to SMEs. The recent financial crisis has forced SMEs to look for new forms of finance as an alternative to bank financing, which is the main reason why alternative equity and fixed income markets are growing in many developed and developing economies (Young et al., 2008). The OECD Principles of Corporate Governance (PCG-1999-2004-2015) try to respond to CG developments to reflect the experiences of OECD and non-OECD countries. A cross-country analysis of similarities and differences in the debt maturity structure (DMS) of listed SMEs from the point of view of the CG of two economic environments is a topic that still has not been analysed. This comparison is of special interest given Argentina's interest and prospects of joining the OECD nearly in the future. The conclusions of this work are useful for this country and others that wish to follow this path.

In this introduction we will comment some characteristics of the studied countries. SMEs represent a very important part of the economy in almost every country in the world. In Spain, SMEs represent $99.89 \%$ of all firms, and in Argentina, they represent $99.7 \%$. When such financ- 
ing comes from capital markets, they are affected by the application of the PCG. These principles are actively applied by governments, policymakers, investors, firms, managements, and stakeholders and have been adopted by the Financial Stability Forum as one of the Twelve Key Standards for Sound Financial Systems.

In Spain, there is an international alternative equity market for growing enterprises (MAB_GE). This market belongs to and is operated by the Bolsas y Mercados Españoles Sistemas de Negociación, S.A. BMESN (2015) issued the General Rules of MAB_GE aimed at regulating the operation of a multilateral trading system with specific characteristics. Among the main regulated aspects are three internal CG guidelines: i) the limited review of accounts every 6 months, ii) control of the figure of nominated advisors, and iii) the obligation to have a commission of independent auditors. According to this MAB_GE General Regulation (2015), the Spanish listed SMEs were not subject to CG guidelines until 9 March 2016 (Table 1).

In Argentina, the National Securities Commission (NSC) regulations (2013) established the NSC SME Regime for companies wishing to issue securities representing equity or debt in the Argentine capital markets (Chapter VI, Title II). The SME segment of the Buenos Aires Stock Exchange (SME_BASE) is an alternative equity and fixed income market, and firms can obtain financing by the discounting of deferred payment checks, financial trusts, and the issuance of corporate bonds and shares. The information requirements are smaller for listed SMEs, regarding the presentation of quarterly financial statements and the exemption of the requirement to have an audit committee. Marketable securities included in this regime can be acquired only by qualified investors.

Insert Table 1 about here 
There are not issued rules currently within or outside the OECD for SMEs, but the PCG have been adopted in some cases. Spain applies the EU's rules and internal market recommendations. In Spain, the MAB_GE-listed firms must follow its own regulations on CG. In Argentina, the NSC requires firms to present a Corporate Governance Code (Res.NSC 606/12) based on the principle of comply or explain, but SMEs are exempted from this requirement. Klappler and Love (2004) provide evidence that the average firm-level CG is lower in countries with weaker legal systems. In addition, firm-level CG provisions matter more in countries with weak legal environments (Argentina is not included in this study). Siems and Alvarez-Macotela (2014) wonder if the PCG, which were designed for developed and rich countries, can be adapted to less developed ones.

According to Baker and Martin (2011), there are differences between countries that have a legal system based on civil law and those that apply common law. In the first one, the companies have more debt in the short term. Although Argentina and Spain have the same legal system, French civil law, the effectiveness of economic and financial institutions is higher in Spain, as shown by the CLEAR Opacity Index (Milken Institute 2009). Therefore, given the different economic and institutional contexts of both countries, this paper focuses only on whether the countries belong to the group of OECD countries.

The paper presented here attempts to answer the following research questions: i) Are there any differences in the corporate governance structures of listed SMEs in an OECD country (Spain) and a non-OECD country (Argentina)? If such differences do exist, ii) do these differential GC attributes have any effect on the debt maturity structure (DMS)? 
We contribute to the literature as the following ways. First, we provide evidence about the financial impact on the short-term liabilities (STL) ratio of CG attributes in listed SME. Second, as far as the authors know, this is the first article to analyse the CG attributes of listed SMEs in an OECD country and a non-OECD country. Third, the paper presents CG data derived from an $a d$ hoc basis elaborated from different websites and databases.

\section{THEORETICAL FRAMEWORK AND HYPOTHESES}

\subsection{Ownership concentration and the STL ratio}

Classical capital structure theory classifies DMS explanations into three categories: contracting costs, signalling hypotheses, and taxes (Barclay and Smith, 1995). In addition, macro-economic factors can also affect DMS (Caprio and Demirguc-Kunt 1998). In fact, in emerging countries, firms issue mostly short-term debt, in contrast to developed countries, where long-term debt predominates (Booth et al., 2001). For developed countries, some previous studies analyse the relationship of CG attributes and DMS. We find a group of studies based on large listed firms, e.g., Shyu and Lee (2009), Lee and Chan (2013) for Taiwan; García-Teruel and Martínez-Solano (2010) for Spain; Dasilas and Papasyriopoulos (2015) for Greece, and Iona and Leonida (2016), Iona, Leonida and Ventouri (2017) for UK, among others. A second group of studies analyses private unlisted SMEs, e.g. Díaz-Díaz, García-Teruel and Martínez-Solano (2016) for Spain. Dasilas and Papasyriopoulos (2015) compare the impact of the corporate governance characteristic on the credit rating and capital structure of the listed large and SME Greek firms.

The CG attributes that are studied in OECD countries include ownership concentration, main shareholder participation, board structure and women as members of the board. For nonOECD countries, few studies have focused on the relationship between CG characteristics and 
DMS, and most of them are based on large public firms: Arslan and Karan (2006) for Turkey; Lemma and Negash (2012, 2016) for African countries; and Martins, Schiehll, and Terra (2017) for Brazil and Chile, among others. Briozzo, Albanese and Santoliquido, (2017) studied this relationship for Argentinean SMEs.

The CG characteristics that are studied in non-OECD economies include the ownership concentration and main shareholder participation. Young et al. (2008) observe that in emerging markets such as Latin American countries, there is another added conflict because a feature common of these economies is the great concentration of ownership in few individuals (or families founder) and economic groups. The principal-principal conflict is raised, which arises between the representative manager of the controlling family and other outside investors. The importance of a good CG is that it mitigates conflicts of interest between different participants of a firm and reduces information opacity (Klapper and Love, 2004; Garay and González, 2008; Braga Alvez and Shastri, 2011, Briozzo, Albanese and Santoliquido, 2017).

Short-term debt can serve as an outside monitoring mechanism and can consequently reduce managerial discretion over the firm's free cash flow (Jensen, 1986). A large shareholder can also act as a control mechanism to reduce the conflict of interest between insiders and outsiders (Shleifer and Vishny 1986). Therefore, a negative substitution effect between monitoring by debt holders and large shareholders can emerge. That is, there should be a negative association between ownership concentration and short-term debt (Martins, Schiehll, and Terra, 2017). According to previous studies (Garcia-Teruel and Martínez-Solano 2010; in the UK, Marchica, 2008; and in Turkey, Arslan and Karan, 2006), the presence of large shareholders is negatively related to short-term debt differences. Thus, we posit the following hypothesis: 
Hypothesis 1 . The higher the percentage of ownership concentration by the largest shareholder, the lower the STL ratio is.

However, the relationship between ownership concentration and debt maturity may not be linear. Ownership concentration can also induce expropriation effects for debt holders and minority shareholders (principal-principal conflicts). This problem is especially important in countries with low investor protection, such as Argentina and Spain, both of which are ruled by French civil law (La Porta et al., 1998). In this case, a large shareholder does not necessarily have a monitoring role such as short-term debt. Therefore, "controlling owners may be interested in signalling to the market their intention to mitigate potential agency costs by using short term debt" (García-Teruel and Martinez-Solano, 2010:476). Lee and Chan (2013), García-Teruel and Martinez-Solano (2010), and Martins et al. (2016), among others, find that the effect of ownership concentration on DMS is non-monotonic ${ }^{1 \cdot}$ On the one hand, it has a positive association with short-term debt for a high tenure for the largest shareholder. On the other hand, this relationship becomes negative at low ownership concentration levels. Consequently, we present the following hypotheses:

Hypothesis $1 b$ (signalling). The higher the percentage of ownership concentration by the largest shareholder, the higher the STL ratio is for firms with a large shareholder with high participation.

Hypothesis 1c (substitution effect between the control role of ownership concentration and STL). The higher the percentage of ownership concentration by the largest shareholder, the lower the STL ratio is for firms with a large shareholder with low participation.

\footnotetext{
${ }^{1}$ A non-monotonic function is a function that is increasing and decreasing on different intervals of its domain.
} 


\subsection{Corporation as main shareholder and the STL ratio}

Business group structures are a prevalent feature of developing countries (Young et al., 2008). The presence of business groups presents another channel through which controlling shareholders can expand control and expropriate wealth from minority shareholders (principal -principal conflicts). Short-maturity debt can be used as a monitoring device, given its frequent renewal, which exposes managers to the evaluation of banks and external investors (Stulz, 2000). Therefore, managers under a weak corporate governance structure will choose more long-term debt for the firm capital structure. Datta, Datta, and Raman (2005) report a statistically significant inverse relation between managerial stock ownership ${ }^{2}$ (a mechanism for aligning manager and owner incentives) and debt maturity. Managerial ownership is negatively related to the long-term debt ratio. Given the higher monitoring role of short-term debt, firms within business groups have an incentive to pursue long-term debt to avoid this control mechanism. According to Wen, Rwegasira, and Bilderbeek (2002), "managers tend to pursue lower financial leverage when they face stronger corporate governance from the board". According to these arguments, we propose the following hypothesis:

Hypothesis 2. The participation of corporations in ownership (business group affiliation) has a negative relation with the STL ratio.

\subsection{Women as members of the board and the STL ratio}

Previous studies have found that gender diversity can positively affect boards' efficiency, given women's tendency for active monitoring (Adams and Ferreira, 2009; Virtanen, 2012; Alves, Cou-

\footnotetext{
${ }^{2}$ Managerial stock ownership is the ratio of equity owned by firm managers.
} 
to and Francisco, 2015), and improve financial performance (Gordon, Hrazdil and Shapiro, 2012). Alves, Couto and Francisco (2015) find that a more gender-diversified board can lead to greater independence in the efficiency of the board of directors and, therefore, lead firms to rely more on long-term sources of funding.

Spain, despite the importance of SMEs in its economy, has not enacted any laws or recommendations so far regarding women and SMEs' CG. Most of the gender studies and CG issues have focused on unlisted Spanish SMEs (Mínguez-Vera and López-Martínez, 2010, 2011; Berenguer, Giraldez-Puig and Cardone-Riportella, 2016, among others). To the best of our knowledge, no previous study has focused on the relationship between gender diversity and capital structure maturity in SMEs. Berenguer, Giraldez-Puig and Cardone-Riportella (2016) confirm the prudential character of women as owners but find no significant results for women as board members. For Argentina, Briozzo, Albanese and Santoliquido (2017) find evidence of relations among different levels of CG and gender diversity. Therefore, we expect that a substitution effect exists between women directors and the of STL, as the control women directors exert replace the monitoring role of STL. Thus, we propose the following:

Hypothesis 3. The participation of women on the board has a negative relation with the STL ratio.

\subsection{Financial statement quality and the STL ratio}

Information disclosure is one of the pillars of good CG practices, among other reasons, because the asymmetric information present in the case of SMEs restricts access to external financing (Briozzo and Cardone-Riportella, 2016). 
In this sense, the following studies give us useful information. Mallin and Ow-Yong (2012) analysed the formal CG aspects in terms of disclosures in the admission document put forward by the Alternative Investment Market (AIM) firms coming to market. The authors also analyse the role of the nominated advisor and nominated broker. Shell and highly geared AIM firms' disclosure exhibits relatively lower levels of CG than recommended by the guidelines. For the authors, the main disincentive to disclose non-mandatory information is potential property cost as the benefits for the competitors of this information. Parsa and Kouhy (2008) focus on the impact of the disclosure social information of listed firms on the AIM. Among the main results, they find that, contrary to the general opinion, SMEs report social information, regardless of their financial situation, because they value the impact of this disclosure of market social reports, which help preserve their corporate reputation.

The external auditor has a key role for external users of financial statements. For Van Caneghem and Van Campenhout (2010), both the level of detail and the quality of the information disseminated in the financial statements of Belgian companies are positively related to the level of indebtedness. Auditing services provided by a Big4 auditing firm have been considered a proxy for audit quality (Van Caneghem and Campenhout, 2010). Moreover, the long-term debt ratio increases (or STL ratio decreases) with the presence of a Big4 auditor, "suggesting that higherquality audits substitute for short-term debt for monitoring purposes" (El Ghoul et al. 2016:718).

Therefore, the disclosure of social reports, the application and disclosure of standards of good governance and the disclosure of auditing services provided by quality audit firms can increase the corporate reputation and affect the capital structure. Therefore, the following can be expected: 
Hypothesis 4. Firms with a Big4 auditor have a lower STL ratio.

\section{DATA AND METHODOLOGY}

\subsection{Data}

We use the following data sets:

- Argentinian SMES_BASE data (25 firms) regard the CG characteristics for the year of the issue prospectus (from 2012 to 2015). Financial data are derived on an ad hoc basis elaborated from website information. For the multivariate analysis, the number of firms with full data decreases from 25 to $19^{3}$.

- Spanish MAB_GE data (31 firms) correspond to the latest available database used (2014). We collected the information from the following databases ${ }^{4}$. i) Data on the board of director characteristics were obtained from the SABI database (https://sabi.bvdinfo.com/version-2016418/home.serv?product=sabineo) and ii) MAB_GE website. For the multivariate analysis, the number of firms with full data goes from 31 to 30 firms.

For both countries, the studied populations include companies from all industries except financial services due to their different financial reporting requirements and financial structure. We analyse one-year data because GC attributes present few variations in the mid-term, and information on some GC attributes for Argentina is not available periodically.

\footnotetext{
${ }^{3}$ The variable with missing data for Argentina is number of employees, which is a measure of firm size. We performed the Little's test of missing completely at random (MCAR) for the employee's variable, and we obtained a pvalue of 0.2605 , which means that the null hypothesis of MACR cannot be rejected. Thus, we keep using the listwise deletion method, given that it does not introduce bias when the data are missing completely at random (MCAR).

4 The Spanish Fixed Income Market is not considered in this study because this alternative capital market was established in 2013 and because there is not enough information. http://www.bmerf.es/esp/QueEs/MARF/MARFIncorporacionBonos.aspx
} 
Given the novelty of SME financing via capital markets, the number of companies trading in these markets is still very small. Except the two pioneer countries in opening alternative markets for SMEs (UK and Canada), alternative capital markets have from 2 to 48 firms in Latin American non-OECD countries, and from 14 to 187 firms in OECD countries. It must be noted that the small number of firms available for the analysis corresponds to the small size of the populations under study, and that our results represent these populations. Small sample problems of inference of the results to the population are no present here because we study the whole population..

\subsection{Variables}

\subsubsection{Dependent Variable}

Short-term liability ratio (STL/TL). We measure DMS as the short-term liabilities to total liabilities. Given that both debt and corporate governance can mitigate agency costs (Jensen and Meckling, 1976; Jensen 1986), a substitution effect between both mechanisms can be expected. Empirical evidence for this inverse relation is reported by several prior studies in listed firms (Wen, Rwegasira, and Bilderbeek. 2002; Jiraporn et al., 2012). These independent variables are measured simultaneously with the dependent variables because we are working with one-year data.

\subsubsection{Independent Variables}

The variables used to represent the four measurable and available corporate governance attributes are as follows.

1.-Ownership Concentration (OC). This is the percentage of ownership of all shares owned by the main shareholder of the firm. This variable is included in most models of CG and firm performance. To test hypotheses H1b (signalling) and H1c (substitution effect), we also create a 
large shareholder dummy (LSD) that takes a value of 1 if the largest shareholder owns $50 \%$ of more of the firm shares.

2.-Participation of corporations in ownership (business groups) (PCO). Number of corporations that are shareholders as a percentage of total shareholders, as a proxy for business groups affiliation.

3.-Number of Woman in the board (WBOARD). Percentage of female directors on the board.

4.-Auditing by one of the Big4 Audit firms (Big4). Measure of whether last year the firm has been audited by one of the world's largest audit firms, which are currently KPMG, Deloitte, PricewaterhouseCoopers and Ernst \& Young.

\subsubsection{Control Variables}

In addition to the explanatory variables, we include controls for other firm-level characteristics that, according to previous studies, may contribute to explaining firms' DMS.

1.-Number of Board Directors (NBOARD). A large board is associated with an ineffective moni-

toring role (Salloum, Azoury and Azzi, 2013), which can facilitate that managers avoid debt maturity structures that enable frequent monitoring (STL).

2.-Firm Size (LSALES). This variable relates to possible economy-of-scale effects. Larger firms face lower information asymmetries, which can facilitate long-term debt financing (Titman and Wessels, 1988). The variable is measured as the natural logarithm of sales. Empirical studies generally support this expected relationship (e.g., Datta, Datta, and Raman, 2005; Marchica 2008, Diaz-Diaz, García-Teruel, and Martínez-Solano, 2016), although some have found the opposite effect (Scherr and Hulburt, 2001). 
3.-Firm Size (FIRMSIZE). We also included the total number of employees of the firm as a control variable.

4.-Firm Age (AGE). This variable relates to changes caused by a firm's life cycle changes. This variable is used to control the level of experience and accumulated resources. It is measured as the number of years a firm has been in existence, and it is expected to exert a positive influence on the long-term debt (Scherr and Hulburt, 2001).

5.-Sector (SEC). We use the industrial sector as a proxy for the asset maturity structure ${ }^{5}$ There are some differences across the industrial sectors. Those firms that belong to the innovation and development sector are more prone to enter MAB_GE because they require greater capital intensity. Firms in the services sector are expected to face higher information asymmetries than are manufacturing firms due to the low investment in fixed tangible assets, which leads to greater use of short-term debt. Previous studies have found that the ratio of fixed assets to total assets is positively related to long-term debt (Arslan and Karan, 2006; Lee and Chang 2013, Diaz-Diaz, García-Teruel, and Martínez-Solano, 2016).

6.-Leverage (LEV). This variable is defined as the ratio of total liabilities to total assets. Highly leveraged firms will seek to control financial risk through longer maturity (Diamond, 1993). Diaz-Diaz et al. (2016) report a positive association between leverage and the long-term debt ratio. 7.-Growth Opportunities (GRO). This variable is defined as the accumulated growth rate in total sales during the two previous years, to proxy for a firm's growth opportunities and hence the severity of underinvestment problems and the need for the control role of short-term liability (Diaz-

\footnotetext{
${ }^{5}$ We do not use the traditional proxy of asset maturity through the ratio of fixed assets to total assets or depreciation, due to inflation distortions in accounting values for Argentina.
} 
Diaz, García-Teruel and Martínez-Solano, 2016). Moreover, STL can act as a signal of good prospects for growing firms (Martins et al., 2016). Barclay and Smith (1995) find that high-growth firms (with potentially higher information asymmetries) issue more short-term debt.

\subsection{Methodology}

First, we analyse the differences in GC attributes between both countries. In this bivariate analysis we use the two-sample Wilcoxon rank-sum (Mann-Whitney) test for continuous variables (a non-parametric test), and Fisher Exact and Pearson chi-squared tests ${ }^{6}$ for binary variables.

To study the relationships between CG attributes in each country (correlation structure), a bivariate analysis is carried out. The Spearman correlation coefficient (a non-parametric test) by ranges is used for pairs of continuous variables (e.g., the size of the company and of the board of directors). The point biserial correlation coefficient and Mann-Whitney test are used to analyse a continuous variable vs. a binary variable (e.g., Big4 auditor and women on board). Estimations are made using StataSE 13.

In the multivariate analysis using least squares regression we test each GC variable individually, to avoid the loose of degrees of freedom and minimize the risk of multicollinearity. Then we run a model that includes all the explanatory GC variables simultaneously for Spanish firms, which represent the larger population. We use different diagnostics checks: the variance

\footnotetext{
6 The Mann-Whitney U test (also called the Mann-Whitney-Wilcoxon test) is a nonparametric test used to test whether two samples are likely to derive from the same population. Fisher's exact test is a statistical significance test used in the analysis of contingency tables, which can be used with small samples. Pearson's chi-squared test is a statistical test applied to sets of categorical data to evaluate how likely it is that any observed difference between the sets arose by chance.
} 
inflation factor (VIF) to check for multicollinearity, the White test and Breusch-Pagan test to check for the homoscedasticity of the residuals, the Ramsey RESET test and Link test to check for misspecification errors, and analysis of the standardized residuals to identify the influence of outliers. Outliers are excluded. It is important to note that the small number of firms available for the analysis responds to the small size of the populations under study, and therefore our results are representative of these populations.

\section{MAIN RESULTS AND DISCUSSION}

\subsection{Corporate Governance attributes}

In this section, we analyse the differences and similarities in CG characteristics for the two countries. First, we present the descriptive statistics of the sample (Table 2).

Insert Table 2 about here

Tables 3 and 4 show a comparison of the countries, and the relation between $\mathrm{CG}$ variables for each country individually. The high ownership concentration observed in Argentina is in line with previous studies for Latin America (Cespedes, González, and Molina, 2010). Spanish companies hire a greater proportion of Big4 Auditing firms, a feature that is practically absent in Argentina. Regarding control variables, Argentinean firms are older and larger (considering employees and sales). The difference for assets and leverage should be interpreted carefully due to inflation distortions in accounting data for Argentina ${ }^{7}$. Argentinean firms have a higher STL ratio, as expected in an emerging country, with a weak legal system and high corruption (Turk

7. The International Accounting Standard 29 (IAS 29, Financial Reporting in Hyperinflationary Economies) describes as a quantitative characteristic of the existence of hyperinflation a three-year cumulative inflation rate exceeding $100 \%$. The cumulative inflation rate in Argentina is close to or above this limit depending on the consulted source. However, inflation accounting is suspended in Argentina since 2003. It must be noted that inflation distortions particularly affect accounting measures of fixed assets and net worth. 
Ariss, 2016). The difference for growth (GRO) can be explained mostly by the high inflation process present in Argentina since 2007. ${ }^{8}$ Spanish firms have larger boards, higher participation of corporations as shareholders, and lower concentration in the hands of the main shareholder. Since there are no previous studies in Spain for these firms, we cannot comment on whether the same or different behaviour occurs.

\section{Insert Tables 3 and 4 about here}

Tables 5 and 6 show that the relationship between CG variables is different for both countries. In Argentina (Table 5), statistically significant results appear for the direct relation between the percentage of shareholders that are corporations (PCO) and the ownership concentration (OC). This result shows the ownership structure of business groups in Argentina.

\section{Insert Tables 5 and 6 about here}

In Spain (Table 5), board size is negatively related with main shareholder ownership. Interestingly, female participation on the board is positively related to economic groups (participation of corporations in ownership, PCO). A Big4 auditor is positively related to ownership concentration. Finally, a higher concentration of property, which implies greater risks for minority shareholders, can be compensated with higher quality informative if firms are being auditing by one of the Big4 auditing firms.

\subsection{Corporate governance impact on the STL ratio}

\footnotetext{
${ }^{8}$ In the multivariate analysis, we do not include total assets (TA) as a control variable due to the levels of inflation presented by the Argentinian economy.
} 
We analyse the effects of CG attributes on the STL ratio for Argentina and Spain (Table 7). Given the small nature of the populations, a set of different model specifications was estimated for each explanatory variable to check the robustness of the results. ${ }^{9}$

For both countries we observe a non-significant effect of ownership concentration on the STL ratio (Table $7 \mathrm{M} 1$ ), thus we find no support for $\mathrm{H} 1$ and $\mathrm{H} 1 \mathrm{a}$. This result remains unchanged after controlling for large shareholder dummy (M2). However, when running the model including all GC variables simultaneously for Spanish firms only (M6), ownership concentration for enterprises with a large shareholder with high participation shows a positive relation with the STL ratio, as expected by $\mathrm{H} 1 \mathrm{~b}$ (signalling hypothesis). This effect is consistent with Lee and Chan (2013), García-Teruel and Martinez-Solano (2010), and Martins et al. (2016).

Insert Table 7 about here

For Argentina and Spain (M3), participation in business groups (other corporations as4shareholders) has a negative effect on the STL ratio, which gives support to $\mathrm{H} 2{ }^{10}$. M4 and M6 in Table 7 show the negative effect of the participation of women on the board for Spanish firms, which brings support for H3. Then, we analyse the effect of a Big4 auditor on STL ratio (M5 Table 7). The results show a strong negative effect of Big4 auditor for both countries, which gives support to $\mathrm{H} 4$.

\footnotetext{
${ }^{9}$ The significance of the individual-level results is robust to different model specifications and the incorporation of control variables. For space reasons, in this section, we show only the estimations for independent variables with significant results (one estimated model for each GC attribute) and we also include a model with all GC variables for Spanish firms. Data is available upon request.

${ }^{10}$ This relation is robust, even after controlling for the main shareholder ownership concentration. Different specifications to control the robustness of the results are not displayed here for space reasons.
} 
Regarding M6 in Table 7, which shows the results for the joint estimation of the GC variables for Spanish firms, it must be noted that besides the result for ownership concentration, participation of women in the board (WBOARD) shows the same sign and significance as M4 in Table 7. However, the risk of multicollinearity is high as shown by the VIF, which in addition to the lack of degrees of freedom can explain the loose of statistical significance at individual level for the other GC variables (Big 4 and PCO). Finally, for control variables we observe that firm size measured by number of employees has a positive effect in all estimated models.

\subsection{Discussion}

As a summary, in Spain, the ownership structure (main shareholder concentration and corporations as shareholders) has a positive effect on the STL ratio when a large shareholder with high participation exits. We do not find support for a U-shaped relationship between ownership concentration and DMS, as found by previous studies. The presence of corporations as shareholders, a proxy for the participation of business groups, has a negative effect on the STL ratio in both countries (H2). This can be interpreted as a way to avoid the monitoring role of STL, but also it shows that firms within business groups have access to long-term credit because of the backup that the business group gives. Regarding the effects of the participation of women on the board for Spanish firms, we find a significant negative effect, which brings partial support for H3. This result is in favour of promoting gender diversity in firm boards. Finally, the effect of a Big4 auditor has a strong negative effect on the STL ratio for both countries, which gives support to H4. Our findings support the view that the financial statements of companies that are not audited by a Big4 firm prevent companies from using long-term funds. 
We can conclude that the influence of CG attributes on DMS varies among countries, the results support $\mathrm{H} 1 \mathrm{~b}$ (ownership concentration under de signalling hypothesis) only for Spain, $\mathrm{H} 2$ (corporations as shareholders) and H4 (Big4) for both countries, and H3 (women participation on board) only for Spain. Regarding the result for ownership concentration in Spain, it is worth to note that in a country where atomized property is more frequent, the signalling effect of a large shareholder arises as a significant influence compared to Argentina. The participation of women in the board is significant only for Spain, a country with more developed gender legislation than Argentina. These differences between countries can be explained by the diverse economic and institutional environments: weaker legal system, higher corruption, differential regulations, and a high inflation process present in Argentina.

\section{CONCLUSIONS}

The firm's capital structure is one of the topics of corporate finance that continues to concern researchers, basically the study of the determinants of firms'capital structure. Several studies have been carried out in order to analyse the determinants of capital structure. In the particular case of the SME, the objective of this paper is to analyse which aspects of corporate governance policy influence on the DMS. The empirical literature on corporate governance and financial decisions mainly refers to large firms and unlisted SMEs. We analysed the following attributes of the CG mechanism: property structure (ownership concentration and corporations as main shareholders); the participation of women on the board, and the intervention of a Big4 in external audit functions.

The study focusses specifically on the case of listed SMEs, since there are scarce studies which focus on these firms, mainly because capital markets for SMEs are indeed new and small. 
In many countries, the recent financial crisis has led SMEs to seek alternatives to bank financing through alternative capital markets. Additionally, the OECD Principles of Corporate Governance try to respond to CG developments in OECD countries. As far as we know, it is not observed in the literature many works that address the listed SME's corporate government in non-OECD countries. A cross-country analysis of similarities or differences on the capital structures of listed SMEs from the point of view of the CG of two economic environments: Argentina, a non-OECD country, and Spain an OECD country are analysed. Both countries have alternative investment markets for SMEs with a similar trajectory, while the characteristics of the companies that participate there are similar as well.

Our results are relevant to SME owners and managers because they suggest that the adoption of good governance practices, which are costly in nature, are offset by the cost savings of long-term financing to which they have access. In the same way, the application of good governance practices, transmit confidence to capital markets, which translates into higher participation of investors. According to Desilas and Papasyriopoulos (2015), these agents seek the balance between capital and debt in the long-term in order to guarantee the viability of the company, while recognizing that the influence of CG attributes on the capital structure of Greek listed SMEs is less evident compared with large firms. The authors attribute this to the active involvement of owners in the management of SMEs, which reduces the need for shareholders to bear the costs of monitoring agents.

This study also provides regulators with information for developing standards that help efficient borrowing in terms of seeking funding in alternative capital markets rather than borrowing. A one-size-fits-all policy is likely to place substantial cost on the smallest first. Therefore, as 
in other countries (e.g., Canada), flexible regulatory standards may be preferable because not all rolls are appropriate for all firms according to Gordon, Hrazdil, and Shapiro (2012).

This study allows us to ask as a future research question if the impact of the CG policy on the capital structure affects listed and non-listed Spanish SMEs in a same or different way. In addition, it could be analysed whether the behaviour of the SMEs in relation to the application of CG policies, changes in times of prosperity compared to times of financial crises.

A limitation of this study is the numbers of firms included in the analysis. Capital alternative markets are very news, so the number of firms trading in these markets is still very small. Another limitation of this study is that (because of data restrictions) the one-year nature of the analysis does not allow us to consider dynamic effects on the DMS; this could be an interesting avenue for further research.

\section{References}

Adams, R.B., and Ferreira, D. (2009), "Women in the boardroom and their impact on governance and performance". Journal of Financial Economics, vol 94 № 2, pp291-309.

Alves, P., Couto, E.B. and Francisco, P.M. (2015), "Board of directors' composition and capital structure". Research in International Business and Finance, vol 35, pp 1-32.

Arslan, Ö., and Karan, M. B. (2006), “Ownership and control structure as determinants of corporate debt maturity, a panel study of an emerging market". Corporate Governance, An International Review, vol 14 No 4, 312-324.

Baker, H. K., and Martin, G. S. (2011), Capital structure and corporate financing decisions, theory, evidence, and practice, vol. 15, John Wiley \& Sons.

Barclay, M. K. and Smith, C.W. (1995), "The maturity structure of corporate debt". The Journal of Finance, vol 50 No 2,pp 609-631. 
Berenguer, E., Giraldez-Puig, P. and Cardone-Riportella, C. (2016), "Moderation effect of gender diversity on exporting activity of Spanish SMEs in times of crisis". Spanish Journal of Finance and Accounting, vol 45 No 3, pp300-326.

Bolsas y Mercados Españoles (2015), “Sistemas de Negociación S.A. Mercado Alternativo Bursátil, Reglamento General", available at: www.bolsasymercados.es/mab/documentos/Avisos/2016/02/MAB_Aviso_20160210_1.pdf

Booth, L., Aivazian, V., Demirguc-Kunt, A., and Maksimovic, V. (2001). "Capital Structures in Developing Countries". Journal of Finance, vol 56, pp 87-130.

Braga Alves, M. and Shastri, K. (2011), “Corporate Governance, Valuation, and Performance, Evidence from a Voluntary Market Reform in Brazil”. Financial Management vol 40,pp 139-157.

Briozzo, A., Albanese D., and Santolíquido, D. (2017), “Corporate governance, financing, and gender, A study of SMEs from Argentinean Securities Markets" Contaduría y Administración, vol 62, pp 358376.

Briozzo, A., and Cardone-Riportella, C. (2016), "Spanish SMEs' Subsidized and Guaranteed Credit during Economic Crisis, A Regional Perspective”. Regional Studies, vol 50 No3,pp 496-512.

Cabrera, F. (2016), "Ministerio de Producción en La Nación. Las pequeñas y medianas empresas son el corazón productivo de la Argentina" available at: www.lanacion.com.ar/1918969-las-pequenas-ymedianas-empresas-son-el-corazon-productivo-de-la-argentina.

Caprio, G. and Demirgug-Kunt, A. (1998), "The role of long-term finance, theory and evidence". World Bank Research Observer, vol 13 No 2, pp 171-189.

Céspedes, J., González, M. and Molina, C.A. 2010. "Ownership and capital structure in Latin America”. Journal of Business Research, vol 63 No 3, pp 248-254.

Comisión Nacional de Mercado de Capitales CNMV, available at: www.cnmv.es/portal/home.aspx CLEAR Opacity index in Milken Institute (2009), available at: http,//assets1b.milkeninstitute.org/assets/Publication/ResearchReport/PDF/InstituteOpacityIndex_A pr8.pdf 
Dasilas, A. and Papasyriopoulos, N. (2015) "Corporate governance, credit ratings and the capital structure of Greek SME and large listed firms". Small Business Economic, vol 45 No 1 pp 215-244.

Datta, S., Datta; M.A.I., and Raman, K. (2005), "Managerial stock ownership and the maturity structure of corporate debt". The Journal of Finance, vol 60 No 5, pp 2333-2350.

Diamond, D.W. (1993), "Seniority and maturity of debt contracts.” Journal of Financial Economics, vol 33, pp 341-368.

Díaz-Díaz, N. L., García-Teruel, J.P. and Martínez-Solano, P. (2016), “Debt maturity structure in private firms, Does the family control matter?" Journal of Corporate Finance, vol 37, pp 393-411.

El Ghoul, S., Guedhami, O., Pittman, J.A. and Rizeanu, S. (2016), "Cross-Country Evidence on the Importance of Auditor Choice to Corporate Debt Maturity”. Contemporary Accounting Research, vol 33 No 2, pp 718-751.

EUROSTAT (2015) available at:

http,//ec.europa.eu/eurostat/statistics explained/index.php/Waste_statistics

Garay, U., and González, M. (2008) "Corporate Governance and Firm Value, The Case of Venezuela." Corporate Governance, An International Review, vol 10, pp 194-209.

García-Teruel, P.J., and Martínez-Solano, P. (2010), “Ownership structure and debt maturity, new evidence from Spain". Review of Quantitative Finance and Accounting, vol 35 No 4, pp 473-491.

Gordon, I.M., Hrazdil, K. and Shapiro, D. (2012), “Corporate governance in publicly traded small firms, A study of Canadian venture exchange companies". Business Horizons, vol 55 No 6, pp 583-591.

International Accounting Standard 29 - Financial Reporting in Hyperinflationary Economies IAS 29, available at: www.iasplus.com/en/standards/ias/ias29. 
Iona, A. and Leonida, L. (2016) "Suboptimal financial policies and executive ownership in the UK, evidence from a pre-crisis". Corporate Governance, The international journal of business in society. Vol 16 No 1, pp 187-210.

Iona, A., Leonida, L. and Ventouri, A. (2017), "Does executive ownership lead to excess target cash? The case of UK firms". Corporate Governance, The international journal of business in society, vol 17 No 5, pp 876-895.

Jensen, M.C., and Meckling, W. (1976), “Theory of the firm, managerial behavior, agency costs and ownership structure". Journal of Financial Economics, vol 3, pp 305-360.

Jensen, M.C. (1986), “Agency Cost of Free Cash Flow, Corporate Finance and Takeovers". American Economic Review, vol 76 No 2, pp 323-329.

Jiraporn, P., Kim, J.C., Kim, Y.S., and Kitsabunnarat, P. (2012), “Capital structure and corporate governance quality, Evidence from the Institutional Shareholder Services ISS”. International Review of Economics \& Finance, vol 22 No 1, pp 208-221.

Klapper, F., and Love, I. (2004), “Corporate Governance, Investor Protection, and Performance in Emerging Markets.” Journal of Corporate Finance, vol 10, pp 703-728.

Lee, Y.C., and Chan, W.H. (2013), "How controlling shareholders impact debt maturity structure in Taiwan”. Journal of International Financial Management \& Accounting, vol 24 No 2, pp 99-139.

Lemma, T.T., and Negash M. (2012). " Debt maturity choice of a firm, evidence from African countries". Journal of Business and Policy Research, vol 7 No 1, pp 60-92.

Lemma, T.T., and Negash, M. (2016), "Corporate ownership patterns in developing countries". Corporate Ownership and Control, vol 13 No 2, pp 101-112.

Mallin, C., and Ow-Yong, K. (2012), "Factors influencing corporate governance disclosures, evidence from Alternative Investment Market AIM companies in the UK". The European Journal of Finance, vol 18 No 6, pp 515-533. 
Marchica, M. T. (2008), On the Relevance of Ownership Structure in Determining the Maturity of Debt. EFA 2007 Ljubljana Meetings Paper.

Martins, H.C., Schiehll, E., and Terra, P.R.S. (2017), "Country-level Governance Quality, Ownership Concentration, and Debt Maturity, A Comparative Study of Brazil and Chile". Corporate Governance, An International Review Corporate. Available at: https,//doi.org/10.1111/corg.12192

Mínguez-Vera, A., and López-Martínez, R. (2010), "Female Director and SMEs. An empirical Analysis”. Journal of Global Strategic Management, vol 08, pp 34-46.

Mínguez-Vera, A., and López-Martínez, R. (2011), “Gender and management on Spanish SMEs, an empirical analysis". The International Journal of Human Resource Management, vol 22 No 14, pp $2852-2873$.

National Securities Commission NSC, (2012), "Código de Gobierno Societario", available at: http,//servicios.infoleg.gob.ar/infolegInternet/anexos/195000-199999/198057/norma.htm

National Securities Commission NSC, (2013), “2013 Regulatory framework” available at: www.cnv.gob.ar/leyesyreg/CNV/esp/TOC2013.pdf

Parsa, S., and Kouhy, R.J. (2008), "Social Reporting by Companies Listed on the Alternative Investment Market”. Journal of Business Ethics, vol 79 No 3, pp 345-360.

Salloum, C. C., Azoury, N. M., and Azzi, T. M. (2013), "Board of directors' effects on financial distress evidence of family owned businesses in Lebanon". International Entrepreneurship and Management Journal, vol 91, pp 59-75.

Siems, M.M., and Alvarez-Macotela, O. (2014), The OECD Principles of Corporate Governance in Emerging Markets, A Successful Example of Networked Governance?. Networked Governance, Transnational Business and the Law, pp 257-284.

Shleifer, A., and Vishny. R.W. (1986), "Large shareholders and corporate control". Journal of Political Economy, vol 94 No 3, Part 1, pp 461-488. 
Scherr, F. C., and Hulburt, H.M. (2001), “The debt maturity structure of small firms”. Financial Management, vol 30 No 1, pp 85-111.

Shyu, Y.W., and Lee, C.I. (2009), "Excess Control Rights and Debt Maturity Structure in FamilyControlled Firms”. Corporate Governance, An International Review, vol 17 No 5, pp 611-628.

Spanish Stock Exchange Bolsas y Mercados Españoles, available at: www.bolsasymercados.es/esp/Home

Stulz, R.M. (2000), "Financial Structure, Corporate Finance, and Economic Growth". International Review of Finance, vol 1 No 1, pp 11-38.

Titman, S., and Wessels, R. (1988), "The Determinants of Capital Structure Choice”. Journal of Finance, vol 43 No 1, pp 1-19.

Turk Ariss, R. (2016), "Legal systems, capital structure, and debt maturity in developing countries". Corporate Governance, An International Review, vol 24 No 2, pp 130-144.

Van Caneghem, T., and Campenhout, G. (2010), "Quantity and quality of information and SME financial structure". Small Business Economics, vol 39 No 2, pp 341-358.

Virtanen, A. (2012), Women on the boards of listed companies, Evidence from Finland. Journal of Management \& Governance, vol 16 No 4, pp 571-593.

World Bank Enterprise Surveys (2010), available at:

www.enterprisesurveys.org/data/exploreeconomies/2010/argentina\#finance--size

Wen, Y., Rwegasira, K., and Bilderbeek, J. (2002), "Corporate governance and capital structure decisions of the Chinese listed firms". Corporate Governance, An International Review, vol 10 No 2, pp 7583.

Young, M. N., Peng, M.W., Ahlstrom, D., Bruton, G.D., and Jiang, Y. (2008), "Corporate Governance in Emerging Economies”. Journal of Management Studies, vol 45, pp 196- 220. 


\section{TABLE 1}

\section{Geographic and temporal context}

\begin{tabular}{|c|c|c|c|c|c|c|c|c|c|}
\hline & \multicolumn{5}{|c|}{ Argentina } & \multicolumn{4}{|c|}{ Spain } \\
\hline SME definition & \multicolumn{5}{|c|}{$\begin{array}{l}\text { The Argentinian Secretary of Entrepreneurship and Small and } \\
\text { Medium Enterprises defines the maximum amount of annual } \\
\text { sales to be considered an SME, based on annual sales and } \\
\text { sector of activity. The current legislation at the time of the } \\
\text { study was Resolution } 11 / 2016 \text {, which establishes a maximum } \\
\text { annual sale of } 33.75 \text { for industry and mining, trade } 40.63 \\
11.25 \text { services, construction and } 10 \text { agricultural } 16.88 \text { (in } \\
\text { millions of euros, exchange rate peso-euro average } \$ / € 16 \text { for } \\
\text { the first semester of 2016). }\end{array}$} & \multicolumn{4}{|c|}{$\begin{array}{l}\text { European Union Recommendation 2003/361/EC } \\
\text { "The category of SMEs is made up of enterprist } \\
\text { which employ fewer than } 250 \text { persons and whic } \\
\text { have an annual turnover not exceeding } 50 \text { millio } \\
\text { euro, and/or an annual balance sheet total ne } \\
\text { exceeding } 43 \text { million euro." }\end{array}$} \\
\hline $\begin{array}{l}\text { SMEs in the country } \\
\text { economy }\end{array}$ & \multicolumn{5}{|c|}{$\begin{array}{l}\text { In Argentina, } 99.7 \% \text { of the companies are micro, small or } \\
\text { medium enterprises. Together, they generate } 70 \% \text { of private } \\
\text { registered employment (Cabrera, 2016). }\end{array}$} & \multicolumn{4}{|c|}{$\begin{array}{l}\text { In the EU-28, on average, } 99.8 \% \text { of total firm } \\
\text { generate around } 60 \% \text { of the gross value added an } \\
\text { employ nearly of } 70 \% \text { of the total employmes } \\
\text { (EUROSTAT, 2015). }\end{array}$} \\
\hline SMEs Bank financing & \multicolumn{5}{|c|}{$\begin{array}{l}\text { In Argentina } 37.9 \% \text { of small firms (fewer than } 20 \text { employees) } \\
\text { and } 58.9 \% \text { of medium firms ( } 20 \text { to } 99 \text { employees) have a bank } \\
\text { loan or line of credit. (World Bank Enterprise Surveys, 2010). }\end{array}$} & \multicolumn{4}{|c|}{$\begin{array}{l}\text { On average } 70 \% \text { of the EU-SMEs are dependent ol } \\
\text { bank financing. In Spain, the percentage is } 80 \% \text {. I } \\
\text { Asia } 50 \% \text { and in USA } 20 \% \text { (BME, 2016). }\end{array}$} \\
\hline $\begin{array}{l}\text { Alternative } \\
\text { Markets }\end{array}$ & \multicolumn{5}{|c|}{$\begin{array}{l}\text { Argentinean SME segment of Buenos Aires Stock Exchange } \\
\text { (SME_BASE). }\end{array}$} & \multicolumn{4}{|c|}{$\begin{array}{l}\text { Mercado Alternativo Bursátil - Empresas en Crec } \\
\text { miento y Mercado Español de Renta Fija (MERF). }\end{array}$} \\
\hline CG rules & \multicolumn{5}{|c|}{$\begin{array}{l}\text { NSC requires listed firms to present a Corporate Governance } \\
\text { Code (Res.NSC 606/12) based on the principle of comply or } \\
\text { explain. SMEs are exempted from this requirement. }\end{array}$} & \multicolumn{4}{|c|}{$\begin{array}{l}\text { General Rules for MAB_GE.: i) the limited revier } \\
\text { of accounts every } 6 \text { months, ii) control of the figur } \\
\text { of nominated advisors, and iii) the obligation t } \\
\text { have a commission of independent auditors. }\end{array}$} \\
\hline Legal system & \multicolumn{5}{|c|}{ French Civil Law } & \multicolumn{4}{|c|}{ French Civil Law } \\
\hline Inflation rate $(*)$ & \multicolumn{5}{|c|}{$33.48 \%$ (2013-2016 annual average) } & \multicolumn{4}{|c|}{$0.125 \%$ (2013-2016 annual average) } \\
\hline $\begin{array}{l}\text { Opacity Index } \\
\text { Milken Institute (2009), } \\
\text { C LE A R }(* *)\end{array}$ & \multicolumn{5}{|c|}{42} & \multicolumn{4}{|c|}{$\begin{array}{l}\text { World Bank Development indicators for Spair } \\
\qquad 26\end{array}$} \\
\hline \multicolumn{10}{|c|}{$\begin{array}{l}\text { Source: Authors Elaboration. (*) Instituto Provincial de Estadística de San Luis for Argentina. World Bank Development indicc } \\
\text { tors for Spain. }(* *) \text { The opacity index varies from } 0 \text { to } 100 \text {; a higher value indicates higher opacity. The Opacity Index is con } \\
\text { posed of the following indicators: C: Corruption, L: Legal System, E: Enforcement, A: Exposure and accounting standards, and F } \\
\text { Regulatory quality. In all cases, a higher value indicates poorer quality of the measured variable. Source: Milken Institute (2009 } \\
\text { C L E A R. }\end{array}$} \\
\hline \multicolumn{10}{|c|}{$\begin{array}{c}\text { TABLE } 2 \\
\text { Descriptive statistics }\end{array}$} \\
\hline \multicolumn{6}{|c|}{ Argentina } & \multicolumn{4}{|c|}{ Spain } \\
\hline \multicolumn{2}{|l|}{ Variables } & Mean & St. dev & Min & Max & Mean & St. dev & Min & Max \\
\hline \multicolumn{2}{|c|}{ Dependent variable: STL/ TL } & $84.71 \%$ & $17.8 \%$ & $26.7 \%$ & $100.0 \%$ & $56.97 \%$ & $18.6 \%$ & $23.4 \%$ & $86.5 \%$ \\
\hline \multicolumn{2}{|c|}{ WBOARD } & $19.02 \%$ & $23.3 \%$ & $0.0 \%$ & $66.7 \%$ & $9.63 \%$ & $10.7 \%$ & $0.0 \%$ & $33.3 \%$ \\
\hline \multicolumn{2}{|l|}{ OC } & $57.42 \%$ & $27.1 \%$ & $22.5 \%$ & $99.9 \%$ & $41.33 \%$ & $25.2 \%$ & $5.0 \%$ & $99.9 \%$ \\
\hline \multicolumn{2}{|l|}{ PCO } & $24.61 \%$ & $33.8 \%$ & $0.0 \%$ & $100.0 \%$ & $67.78 \%$ & $26.0 \%$ & $0.0 \%$ & $100.0 \%$ \\
\hline \multicolumn{2}{|l|}{ NBOARD } & 3.475 & 0.82 & 3.00 & 5.00 & 6.545 & 2.8 & 3.0 & 14.0 \\
\hline \multicolumn{2}{|l|}{ AGE (years) } & 19.5 & 15.90 & 8.00 & 72.00 & 13.2 & 7.84 & 1 & 30.67 \\
\hline \multicolumn{2}{|c|}{ LSALES (thousand euros) } & 9.17 & 1.16 & 7.09 & 12.00 & 7.67 & 2.59 & 0.43 & 11.32 \\
\hline \multicolumn{2}{|c|}{$\begin{array}{l}\text { FIRMSIZE (Number of employ- } \\
\text { ees) }\end{array}$} & 144.66 & 288.24 & 25.00 & 1337 & 89.53 & 140.6 & 2.0 & 511.0 \\
\hline \multicolumn{2}{|c|}{ TA (thousand euros) } & 11,470 & 8,963 & 870.89 & 36,658 & 24,041 & 25,528 & 7 & 116,092 \\
\hline
\end{tabular}




$\begin{array}{lcccccccc}\text { LEV } & 65.67 \% & 13.1 \% & 43.2 \% & 86.1 \% & 54.78 \% & 24.0 \% & 1.4 \% & 88.7 \% \\ \text { GRO } & 75.90 \% & 85.1 \% & -45.3 \% & 378.1 \% & 55.18 \% & 132.6 \% & -99.9 \% & 514.6 \% \\ \text { FIRMAGE (years) } & 19.8 & 14.5 & 7 & 72 & 13.2 & 7.8 & 1 & 30\end{array}$

TABLE 3

Characterization of continuous Corporate Governance and control variables

\begin{tabular}{lccc}
\hline Variables & Argentina & Spain & P-value \\
\hline $\begin{array}{l}\text { Dependent variable: STL/ TL } \\
\text { Independent variables }\end{array}$ & $84.71 \%$ & $56.97 \%$ & 0.000 \\
WBOARD & $19.02 \%$ & & \\
OC & $57.42 \%$ & $9.63 \%$ & 0.176 \\
PCO & $24.61 \%$ & $41.33 \%$ & 0.013 \\
Control variables & & $67.78 \%$ & 0.000 \\
NBOARD & 3.475 & & \\
AGE (years) & 19.5 & 6.545 & 0.000 \\
LSALES (thousand euros) & 9.17 & 13.2 & 0.038 \\
FIRMSIZE (Number of employees) & 144.66 & 7.67 & 0.114 \\
TA (thousand euros) & 11,470 & 89.53 & 0.023 \\
LEV & $65.67 \%$ & 24,041 & 0.032 \\
GRO & $75.90 \%$ & $54.78 \%$ & 0.057 \\
FIRMAGE (years) & 19.8 & $55.18 \%$ & 0.009 \\
\hline
\end{tabular}

Note: Means are shown for each variable. P-values from Mann-Whitney test

TABLE 4

Characterization of binary Corporate Governance and control variables

\begin{tabular}{lcccc}
\hline Variables & Argentina & Spain & P-value & Test \\
Dependent variables & & & & \\
BIG4 & $4.00 \%$ & $33.33 \%$ & 0.001 & Fisher Exact \\
MSC & $0.00 \%$ & $61.29 \%$ & 0.000 & Fisher Exact \\
LSD & $60.98 \%$ & $45.71 \%$ & 0.183 & Pearson \\
Control variables & & & & \\
SEC & $38.10 \%$ & $25.00 \%$ & 0.233 & Pearson \\
\hline
\end{tabular}


Note: The presence of the characteristic is shown for each country. P-values are from the Fisher Exact or Pearson test according to the structure of the contingency table.

TABLE 5

\section{Correlation matrix for Corporate Governance data for Argentina}

\begin{tabular}{lcccc}
\hline & OC & NBOARD & WBOARD & PCO \\
\hline OC & 1 & & & \\
NBOARD & -0.2016 & 1 & & \\
WBOARD & -0.1299 & -0.0688 & 1 & 1 \\
PCO & $0.4824^{* *}$ & -0.1153 & -0.1558 & \\
\hline
\end{tabular}

Note: Big4 calculations not available due to estimation problems for small size samples. The Spearman correlation is computed for pairs of continuous variables. The point biserial correlation is computed for a pair of binary variables with a continuous variable. * notes statistical significance at the $10 \%$ level, $* *$ at the $5 \%$ level, and *** at the $1 \%$ level

TABLE 6

Correlation matrix for Corporate Governance data for Spain

\begin{tabular}{lccccc}
\hline & OC & NBOARD & WBOARD & PCO & BIG4+ \\
\hline OC & $-0.5363^{* * *}$ & 1 & & & \\
NBOARD & 0.2981 & 0.197 & 1 & & \\
WBOARD & 0.2467 & 0.1257 & $0.3582^{*}$ & 1 & \\
PCO & $0.493^{* *}$ & -0.259 & 0.097 & -0.111 & 1 \\
BIG4+ & & &
\end{tabular}

Note: + denotes binary variables. The Spearman correlation is computed for pairs of continuous variables. The point biserial correlation is computed for a pair of binary variables with a continuous variable. * notes statistical significance at the $10 \%$ level, $* *$ at the $5 \%$ level, and $* * *$ at the $1 \%$ level.

TABLE 7

Joint estimations of GC attributes effect on DMS

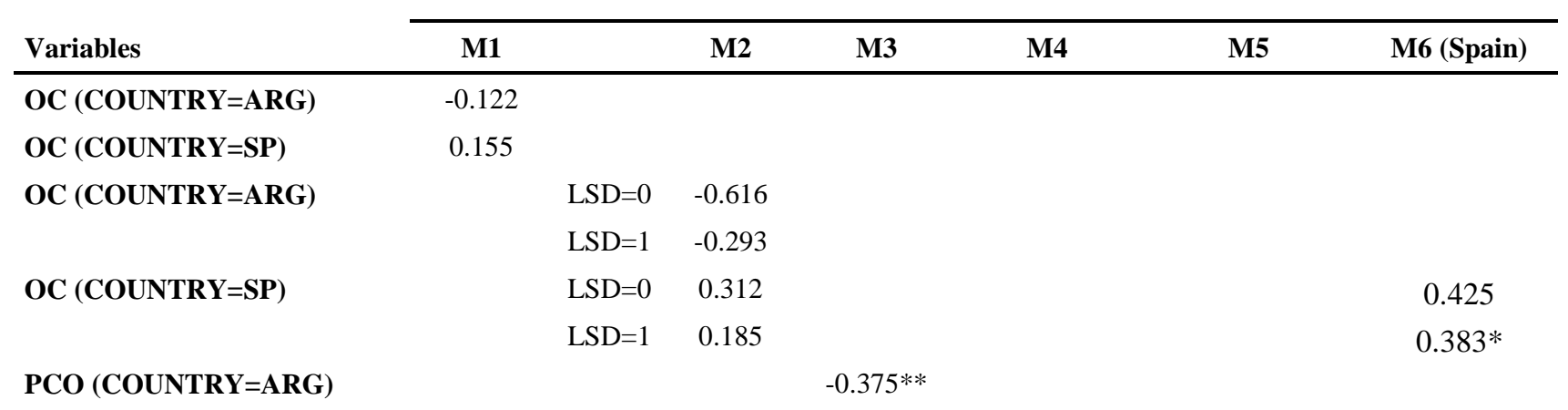


WBOARD(COUNTRY=ARG)

WBOARD(COUNTRY=SP)

BIG 4(COUNTRY=ARG)

BIG4(COUNTRY=SP) $\}$

BIG4

FIRMSIZE

COUNTRY

FIRM AGE

CONST

$\mathbf{N}$

Prob $>$ F

Adj R2

Mean VIF

White's general test (p-value)

Breush-Pagan (p-value)

Ramsey RESET test (p-value)

Link Test (p-value)

Standarized residuals

$0.062 * * *$
-
$0.358 * * *$

$0.614 * * *$
49
0.000
0.594
1.480
0.622
0.830
0.202
0.148
$-1,99 ;$
1.97

0.083

$-0.689 * *$

$-0.834 * *$

$-0.498 * * *$

$-0.292 * * *$

0.006

$-0.135^{* *}$

$0.065 * * * \quad 0.065 *$

$0.036^{* *}$

$0.045^{* *}$

$0.054 *$

$-0.064$

$-0.003$

$-0.002$

$0.737 * * * \quad 0.601 * * *$

$0.555 * * *$

$0.661 * * *$

$0.387 * *$

49

49

49

0.000

49

30

$0.000 \quad 0.000$

0.379

0.422

0.000

0.000

0.473

2.420

1.700

0.389

0.399

1.370

2.640

0.166

0.514

0.411

0.586

0.638

0.748

0.726

0.827

$0.638 \quad 0.324$

0.117

0.319

0.737

0.400

0.184

0.362

0.532

0.785

1,$98 ; 1.93$

$-1.99 ; 1.79$

$-1.98 ; 1.95$

$-1.98 ; 1.91$

$-1.77 ; 1.69$

Note: Variables named Country=Arg show the effect of the variable for Argentina, while those named Country=Sp show the effect for Spain. M6 estimates only for Spain. Results from the least squares regression. Statistical significance is noted with * at the $10 \%$ level, $* *$ at the $5 \%$ level, and $* * *$ at the $1 \%$ level. N: number of firms. Link test shows the p-value of the prediction squared in the STL regression.. Regressions controlled for outliers. 